\title{
PERILAKU VERBAL DAN NONVERBAL DALAM RANAH KESEHATAN PADA MASYARAKAT DI DUSUN TAMBRAN KIDUL KECAMATAN SEMIN KABUPATEN GUNUNGKIDUL (KAJIAN ETNOLINGUISTIK)
}

\author{
Die Bhakti Wardoyo Putro, Inyo Yos Fernandez, Wakit Abdullah \\ Magister Linguistik Deskriptif Pascasarjana Universitas Sebelas Maret \\ die.stevani@gmail.com
}

\begin{abstract}
Die Bhakti Wardoyo Putro. S111408009. Verbal and Nonverbal Behavior in Health Domain in the Community of Tambran Kidul Village, Sub district of Semin Regency of Gunungkidul (Ethnolinguistic Study). Thesis Advisor I: Dr. Inyo Yos Fernandez, Thesis Advisor II: Dr. Wakit Abdullah, M. Hum. Theses: Linguistics Study Program, Mayor interest: Descriptive Linguistics. Post Graduate Program. Sebelas Maret University. Surakarta. 2016.
\end{abstract}

The aims of this study are (1) to describe the view of health and sickness in the cummunity of Tambran Kidul village; (2) to describe verbal and nonverbal behavior in healing and preventing the sickness in the cummunity of Tambran Kidul village; (3) to explain the reasons why verbal and nonverbal behaviors are very essential in healing and preventing the sickness on cummunity of Tambran Kidul village; and (4) to describe mindset, view of life, and worldview in the domain of health on the cummunity of Tambran Kidul village, Semin district, Gunungkidul regency.

This study is a descriptive qualitative. Data in this study consisted of primary data and secondary data. Primary data in the form of words in the event said the treatment and prevention of illness-disease using interviews and observation with informants (curer). Secondary data were obtained from books and journals by using literature study method. The data analysis used were ethno science and distributional method with the phases of analysis of domain, taxonomy, componential, and cultural theme. The result of the data analysis is presented through formal and informal method.

The result of this study shows that (1) there is a view of health and sickness based on cognition system of Javanese cummunity in Tambran Kidul village; (2) there are verbal and nonverbal behaviors such as (a) text of verbal and nonverbal behaviors are in form of micro and macro structures. Micro structure includes introduction, contents, and cover. Macro structures includes setting and scene, participants, purpose dan goal, act sequences, tone or spirit of act, instrumentalities, norms, and genres. (b) co-text which is kinetic or movement and material element (c) cultural, situational, socio-economic, and spiritual context. (3) the verbal and nonverbal behaviors are very essential because of some reasons (a) verbal behaviors is the realization of faith and hope in God; (b) nonverbal behaviors is the realization of a real action and (c) the existence of inner-energy, (4) the mindset of the Tambran Kidul villagers are; keeping a harmony, peaceful and principle of living together, eling lan waspodho remember and keep watch', respecting forefathers, and living plainly.. The view of life are: tepa slira 'mutual respect'; ayom 'peaceful', ayem 'serene', suka 'happy'; asih samaning titah 'love of neighbor'; and nglurug tanpa bala 'attack without troops', sugih tanpa bandha 'rich without possessions', digdaya tanpa aji 'divine power without talisman'. The worldview are: the existence of the highest holly spirit, forefathers dhanyang 'the ancestral spirits who protect the village', and mbok Sri 'mother Sri'.

Keywords: verbal and nonverbal behaviors, text, co-text, context, mindset, view of life, and worldview. 


\section{PENDAHULUAN}

Dusun Tambran Kidul merupakan salah satu dusun di Desa Kalitekuk, Kecamatan Semin, Kabupaten Gunungkidul, Provinsi Daerah Istimewa Yogyakarta. Dusun ini mempunyai luas \pm 383.936 hektar dengan jumlah penduduk \pm 363 jiwa atau $108 \mathrm{KK}^{1}$. Masyarakat dusun Tambran Kidul masih melestarikan warisan budaya, seperti campur sari, rasulan, bersih desa, malam satu suro, tirakatan, adat perkawinan, bancakan, dan pengobatan tradisional. Berhubungan dengan pengobatan tradisional, penelitian ini akan mengulas tentang perilaku verbal dan nonverbal dalam ranah kesehatan visual pada komunitas etnik Gunungkidul di Dusun Tambran Kidul dalam menggali pola pikir, pandangan hidup, dan pandangan dunia.

Meskipun di zaman modern ini masyarakat Tambran Kidul sudah mengenal pengobatan medis, masyarakat tetap mengombinasikan antara pengobatan modern dan tradisional. Hal ini menjadi menarik sebab masyarakat Tambran Kidul masih melestarikan budaya Jawa dan sebagai bentuk menghargai kemajuan teknologi dalam ranah kesehatan. Selain itu, sistem kepercayaan Jawa khususnya masyarakat di Dusun Tambran Kidul menganggap bahwa tidak semua penyakit dapat disembuhkan secara modern sebab tidak semua penyakit disebabkan oleh gejala alami atau penyakit yang bersumber dari fisik manusia. Akan tetapi, ada beberapa penyakit yang bersumber dari roh-roh penunggu, sakit akibat tidak menghormati leluhur, sakit akibat melanggar norma-norma sosial, atau sakit dari seseorang karena merasa iri.

Dalam pengobatan tradisional, masyarakat mengenal sosok tetulung. Tetulung merupakan orang yang dipercaya memiliki kemampuan dalam menyembuhkan penyakit secara fisik dan nonfisik.

\footnotetext{
${ }^{1}$ Informasi ini diambil dari laporan Kuliah Kerja Nyata (KKN) para mahasiswa Universitas Sarjanawiyata Tamansiswa,
Yogyakarta pada tahun 2013 .
} 
Tetulung biasanya melakukan perilaku, baik berupa perilaku verbal maupun nonverbal. Setiap perilaku verbal dan nonverbal yang dilakukan oleh setiap tetulung berbeda-beda, sangat bergantung pada hal yang diajarkan sang guru. Perilaku verbal dan nonverbal yang dimiliki oleh suatu masyarakat merupakan warisan nenek moyang yang diperoleh individu secara turun-temurun dan bersifat kolektif.

Wahyu Widodo (2012) dalam Kidung Warawedha terdapat variasi data dan hanya memfokuskan pada repetisi. Sukarno (2005) mengulas mantra dalam ranah pertanian dan Alip Sugiyanto (2014) meneliti mantra reog yang keduanya lebih memfokuskan pada repetisi berdasarkan perspektif analisis wacana dan stilistika. Robson, Stuart \& Yacinta Kurniasih (2000, 297-302) karakteristik masyarakat Jawa berdasarkan pada beberapa leksikon bahasa Jawa tanpa adanya data yang spesitifk atau ranah tertentu. Sjane F. Walangarei (2013), Katubi (2012), Braker (1999a), Damesi (2013) mengulas mengenai ekspresi nonverbal yang dianalisis berdasarkan makna seniotika. Pada penelitian di atas disimpulkan adanya pola pikir, pandangan hidup, pandangan dunia berdasarkan makna simbolik dari perilaku nonverbal. Oleh karena itu, peneliti mempunyai kesempatan untuk meneliti perilaku verbal dan nonverbal dalam ranah kesehatan pada masyarakat di Dusun Tambran Kidul Kecamatan Semin Kabupaten Gunungkidul. Terdapat struktur mikro dalam ranah kesehatan terdiri dari tiga segmen, yaitu pendahuluan, isi/inti dan penutup. Mmantra pengobatan dan pencegahan sakitpenyakit terdapat nomina penunjuk penyebab sakit. Adanya verba imperatif yang menunjukkan power tutulung. Selain itu, perilaku verbal dan nonverbal juga mengandung nilai-nilai budaya yang dapat diterapkan dalam kehidupan masyarakat tersebut. 


\section{LANDASAN TEORI}

\section{Kajian Etnolinguistik}

Istilah Linguistik Antropologi seringkali tumpang tindih dengan istilah Antropologi Linguistik sehingga dalam praktik kedua istilah itu digunakan secara berbeda, berdasarkan penekanan subjek yang berbeda yaitu dari perspektif yang dominan linguistik atau antropologi. Foley dalam karangan Greenberg (1975), berjudul Anthropological Linguistic penekanan subjek yang lebih dominan berfokus pada kajian linguistik. Namun, dalam karangan Duranti (1997) berjudul Linguistic Anthropology penekanan lebih terarah kepada perspektif antropologi. Dengan demikian, pandangan yang dikemukakan Duranti lebih cenderung identik dengan model Etnolinguistik yang selalu berkembang di Eropa (Fernandez: 2015). Munurut Foley (2001: 1), Linguistik Antropologi adalah bagian dari linguistik yang menaruh perhatian pada bahasa dalam konteks sosial dan budaya yang lebih luas dan juga peran bahasa dalam menempa dan memelihara praktik budaya dan struktur sosial. Pendapat lain dikemukakan oleh Sibarani (2004:50), antropolinguistik adalah cabang linguistik yang mempelajari cariasi dan penggunaan bahasa dalam hubungnannya dengna perkembangan waktu, perbedaab tempat komunikasi, sistem kekerabatan, pengaruh kebiasaan etnik, kepercayaan, etika bernahasa, adat-istiadat, dan pola-pola kebudayaan lain dari suatu suku bahasa.

\section{Etnosains dalam Kajian Etnolinguistik}

Istilah etnosains (ethnoscience) juga dikenal dengan the new ethnography atau cognitive anthropology (Spradley, 1997;xix), dan secara metodologis etnosains dipandang cukup memadai untuk mengungkap aspek pengetahuan manusia yang membimbing perilakunya sehari-harinya. Penekanan etnosains pada sistem atau 
perangkat pengetahuan yang merupakan pengetahuan khas dari suaru masyarakat yang menunjukkan kelompok tersebut bertahan hidup yang dimiliki suatu bangsa lebih tepat lagi suku bangsa atau kepompok sosial tertentu (Ahimsa-Putra dalam Wakit Abdullah, 2013:14).

\section{Tradisi Lisan dalam Kajian Etnolinguistik}

Tradisi lisan adalah kegiatan budaya tradisional suatu komunitas yang diwariskan secara turun-temurun dengan media lisan dari satu generasi ke generasi lain baik tradisi

itu berupa susunan kata-kata lisan (verbal) maupun tradisi lain yang bukan lisan (nonvebal). Jan Harold Brunvand dalam Yapi-Taum (2011: 65-66) membagi bahanbahan tradisi lisan, yaitu:

\section{a. Tradisi Verbal}

Tradisi verbal mencakup lima kategori, yakni (1) ungkapan tradisional termasuk pepatah, peribahasa, dan wasita adi; (2) nyanyian rakyat; (3) bahasa rakyat, seperti dialek, julukan, sindiran, gelar-gelar, bahasa sandi; (4) teka-teki; dan (5) cerita rakyat, seperti dongeng, mitos legenda, sage, cerita jenaka.

\section{b. Tradisi Nonverbal}

Tradisi nonverbal mencakup dua tipologi dasar, yakni (1) tradisi yang berciri material (misalnya mainan, makanan, minuman, peralatan dan senjata, alat-alat musik, pakaian dan perhiasa, obat-obatan, seni kerajinan tangan, dan arsitektur rakyat); (2) tradisi nonmaterial (irama musik gamelan Bali, Jawa, Sunda, dll; menganggukkan kepala, menggelengkan kepala, dan lain sebagainya). 


\section{Mantra dan Jenis Mantra}

Hartanta dalam Widodo (2010: 43-47) membagi mantra berdasarkan fungsi atau gunanya sebagai berikut: (1) Mantra pengasihan yaitu mantra yang memiliki kekuatan untuk memikat lawan jenis atau objek sasaran tertentu yang menjadi sasaran. Objek sasaran akan terpesona dengan sang pengamal mantra. (2) Mantra kanuragan atau mantra aji-aji untuk mencapai kekebalan tubuh. (3) Mantra kasuksman yaitu mantra yang terdapat dalam olah batin atau pendakian ke alam batin yang esoteris. (4) Mantra pertanian yaitu mantra yang digunakan dalam ritual-ritual pertanian ketika menabur benih, memetik panen untuk mencapai keselarasan dengan alam. (5) Mantra penglarisan yaitu mantra yang digunakan untuk menarik datangnya rejeki melalui jalan perniagaan. (6) Mantra penyuwunan yaitu mantra yang digunakan pada saat kegiatankegiatan tertentu untuk memperoleh keselamatan, misalnya, mendirikan rumah, menggali sumur, menebang pohon, dan sebagainya. (7) Mantra panulakan yaitu mantra yang digunakan untuk melindungi diri dari gangguan-gangguan orang-orang jahat atau makhluk halus untuk memperloleh keselamatan. (8) Mantra pengobatan yaitu mantra yang digunakan untuk pengobatan penyakit-penyakit tertentu. (9) Mantra trawangan/ sorog yaitu mantra yang digunakan untuk menembus dimensi alam lain. (10) Mantra pengalarutan yaitu mantra yang digunakan untuk merendam amarah atau emosi seseorang. (11) Mantra sirep atau penglerepan yaitu mantra yang digunakan untuk menidurkan seseorang dalam jangka waktu tertentu (hipnotis). (12) Mantra pengracutan yaitu mantra yang digunakan untuk melarutkan ilmu seseorang ketika menjelang ajal. (13) Mantra dhanyangan yaitu mantra yang digunakan untuk berkomunikasi dengan roh-roh tertentu. 


\section{Struktur Makro dan Struktur Mikro}

Melalui unsur-unsur itu, etnolinguistik mengkaji struktur bahasa tradisi lisan atau tradisi budaya terutama untuk menemukan formula atau kaidah unsur verbal itu. struktur itu boleh berupa struktur makro dan struktur mikro. Dalam tradisi lisan, sebuah teks seringkali didampingi oleh unsur-unsur nonverbal yang disebut dengan "ko-teks" (cotext). Ko-teks berupa unsur kinetik atau unsur material yang kesemuanya penting dipertimbangkan dalam menganalisis struktur teks. Keseluruhan teks dan ko-teks ini menjadi satu kesatuan dalam produksi dan distribusi tradisi lisan. Di samping pentingnya ko-teks, pemahaman makna dan fungsi teks tradisi lisan juga perlu mempertimbangkan konteks tradisi lisan. Konteks tradisi lisan dapat berupa konteks budaya, konteks idiologi, konteks situasi, dan konteks sosial. Struktur mikro adalah struktur teks secara linguistik teoritis. Linguistik teoritis yang dimaksud di sini mencakup tataran bahasa seperti bunyi (fonologi), kata (morfologi), kalimat (sintaksis), wacana (diskursus), makna (semantik), maksud (pragmatik), gaya bahasa (stilistika), dan bahasa kiasan (figuratif) (Sibarani, 20014: 326-330). Struktur makro mengacu pada peristiwa tutur. Menurut Chaer (2010: 47-48), peristiwa tutur adalah terjadinya atau berlangsungnya interaksi linguistik dalam satu bentuk ujaran atau lebih yang melibatkan dua pihak, yaitu penutur dan lawan tutur, dengan satu pokok tuturan, di dalam waktu, tempat, dan situasi tertentu. Dell Hymes ( 1972 ), seorang pakar sosiolinguistik terkenal, bahwa suatu peristiwa tutur harus memenuhi delapan komponen, yang bila huruf-huruf pertamanya dirangkai menjadi akronim SPEAKING. Kedelapan komponen itu adalah Setting and scene, Participants, Ends: Purpose dan goal, Act sequences, Key: tone or spiritof act, Instrumentalities, Norms of interaction and interpretation, Genres. 


\section{Semantik Kultural dalam Kajian Etnolinguistik}

Adapun semantik kultur (cultural semantics) yaitu makna yang dimiliki bahasa sesuai dengan konteks budaya penuturnya (Subroto, 1998). Pendekatan budaya/kebudayaan terhadap arti disebut pula pandangan reduksionise budaya (cultural reductionism). Pandangan ini menyatakan bahwa budaya adalah penentu terakhir terhadap arti atau arti bahasa sepenuhnya ditentukan oleh konteks budaya di mana bahasa itu dipakai (Frawley, 1992:45; Subroto, 2011:17 dalam Wakit Abdullah, 2013:16).

\section{Semiotik dalam Kajian Etnolinguistik}

Berdasarkan hubungan antara penanda dan petandanya ada tiga jenis tanda, yaitu ikon, indeks, dan simbol. Pengertiannya (1) ikon adalah tanda yang penanda dan petandanya menunjukkan ada hubugnan yang bersifat alamiah, yaitu penanda sama dengan petandanya (misalnya gambar, potret, patung). (2) Indeks adalah tanda yang penanda dan petandanya menunjukkan adanya hubungan alamiah yang bersifat kausalitas (misal asap menandai api, mendung menandai hujan). (3) Simbol adalah tanda yang penanda dan petandanya tidak menunjukkan hubungan alamiah; hubungannya arbitrer (semau-maunya) berdasarkan konvensi (misalnya kata ibu (penanda) menandai 'orang yang melahirkan kita', bahasa inggris mother, perancis $L a$ mere). Di samping ketiga tanda itu ada tanda yang disebut (4) simtom (gejala) yaitu tanda yang menunjukkannya petandanya belum pasti (misalnya suhu panas orang sakit sebagai gejala sakit apa?) (Preminger, 1974:980; Lyons, 1997;100-108; Pradopo, 1999: 76) (Wakit, 2013:16-17). 


\section{Pola Pikir, Pandangan Hidup dan Pandangan Dunia}

Pola pikir, menurut Casson (1981:75) adalah inferensi atau integrasi kategori konsep yang diperoleh melalui tindak klasifikasi yang hasilnya merupakan bentuk skemata. Hal ini dapat disimpulkan bahwa pola pikir meliputi model, cara, gagasan, dan proses yang dipakai sebagai pedoman, kesimpulan, dan bentuk konsep (Casson dalam Fernandez, 2015: 41). Pandangan hidup itu sendiri adalah konsep yang dimiliki seseorang atau golongan dalam masyarakat yang bermaksud menanggapi dan menerangkan segala masalah di dunia ini (KBBI, 2008:1011). Adapun pandangan dunia adalah bagaimana masyarakat memandang dunia.

\section{Konsep Sehat dan Sakit Secara Umum}

Menurut WHO (1927), sehat adalah keadaan utuh secara fisik, jasmani, mental, dan sosial dan bukan hanya suatu keadaan yang bebas dari penyakit cacat dan kelemahan. Menurut Zaidin Ali (1998), sakit adalah suatu keadaan yang mengganggu keseimbangan status kesehatan biologis (jasmani), psikologis (mental), sosial, dan spiritual yang mengakibatkan gangguan fungsi tubuh, produktivitas dan kemandirian individu baik secara keseluruhan maupun sebagian (Error! Hyperlink reference not valid.).

\section{METODOLOGI}

Penelitian ini termasuk penelitian deskriptif kualitatif. Metode deskriptif kualitatif ini juga memanfaatkan metode etnografi. Pada penelitian ini, lokasi atau objek penelitian berada di lapangan, yaitu Masyarakat di Dusun Tambran Kidul, Desa Kalitekuk, Kecamatan Semin, Kabupaten Gunungkidul sebagai lokasi utama. Adapun 
lokasi penunjang yaitu di Dusun Mendak, Desa Girisekar, Kecamatan Panggang, Kabupaten Gunungkidul. Lokasi penunjang ini dipilih karena pada lokasi utama ditemukan kesulitan menemukan informan yang menjadi pelaksana tetulung dan sekaligus penganut kepercayaan Kejawen. Selain itu, di Dusun Mendak ditemukan warisan lisan dalam perilaku nonverbal. Data dalam penelitian ini berupa kata-kata dalam praktik pengobatan dan pencegahan sakit-penyakit. Metode penyediaan data yang digunakan dalam penelitian ini adalah metode cakap. Metode cakap diwujudkan lewat teknik dasar dan teknik lanjutan. Teknik dasarnya adalah teknik simak bebas libat cakap, sedangkan teknik lanjutannya adalah teknik rekam dan teknik catat.

Langkah pertama teknik pengumpulan data dalam penelitian ini, dengan melakukan observasi atau penjaringan data dengan menyimak penggunaan bahasa tanpa ikut berpartisipasi dalam proses pembicaraan. Dalam teknik ini, peneliti tidak dilibatkan langsung untuk ikut menentukan pembentukan dan pemunculan calon data kecuali hanya sebagai pemerhati. Untuk memperoleh keabsahan, data temuan empiris harus diuji lagi agar makin terpercaya. Adapun triangulasi data yang digunakan dalam penelitian ini adalah triangulasi sumber data dan triangulasi metode. Metode yang digunakan untuk menganalisis data adalah metode agih dan metode etnosains.

\section{HASIL PENELITIAN DAN PEMBAHASAN}

1. Pandangan sehat dan sakit pada Masyarakat Jawa di Dusun Tambran Kidul dan Dusun Mendak, yaitu (a) Pandangan sehat yaitu suatu keadaan yang seimbang antara batiniah, lahiriah, serta adanya relasi sosial yang baik dalam rangka memenuhi peran dan kewajibannya sebagai makhluk hidup. Peran yang dimaksud adalah manusia yang mampu berperan dalam hal profesi atau 
pekerjaan, jabatan, organisasi dalam masyarakat, dan peran dalam keluarga sebagai orang tua atau anak. Kewajiban yang dimaksud adalah manusia yang mampu memenuhi kewajibannya sebagai kepala rumah tangga yang mampu menafkahi keluar. Anak yang mampu belajar dan berbakti kepada orang tua. Para pemimpin yang mampu bekerja dengan baik dan lain sebagainya. (b) Pandangan sakit adalah keadaan yang tidak seimbang dengan adanya keluahan atau sesuatu yang berbeda antara batiniah, lahiriah, relasi sosial yang mengakibatkan terganggunya aktivitas individu dan sosial sehingga tidak dapat memenuhi peran dan kewajibannya sebagai makhluk hidup. Peran yang dimaksud adalah manusia yang tidak mampu berperan dalam hal profesi atau pekerjaan, jabatan, organisasi dalam masyarakat, dan peran dalam keluarga sebagai orang tua atau anak. Kewajiban yang dimaksud adalah manusia yang tidak mampu memenuhi kewajibannya sebagai kepala rumah tangga yang mampu menafkahi keluar. Anak yang tidak mampu belajar dan berbakti kepada orang tua. Para pemimpin yang tidak mampu bekerja dengan baik dan lain sebagainya.

2. Perilaku Verbal dan Nonverbal dalam Penyembuhan Visual Menurut Sistem Pengetahuan Masyarakat Jawa Dusun Tambran Kidul - Kabupaten Gunungkidul

a. Teks Perilaku Verbal dalam Praktik Penyembuhan

1) Struktur Mikro dalam Ranah Kesehatan

Struktur mikro adalah keseluruan atau rangkaian peristiwa anamnesis ${ }^{2}$ dalam pengobatan dan mencegahan sakit-penyakit yang dilakukan oleh para tetulung. Struktur ini merupakan unsur wajib dalam pengobatan dan pencegahan sakit-penyakit pada masyarakat di Dusun Tambran Kidul,

\footnotetext{
${ }^{2}$ Anamnesis adalah riwayat orang sakit dan penyakitnya pada masa lampau (KBBI).
} 
seperti sakit pegal-pegal, sakit panas, sawang kengkeng, ritual puputan, dan ritual rasulan. Struktur mikro ini terdiri dari tiga segmen, yaitu pendahuluan, isi/inti dan penutup. Pendahuluan berisi salam, maksud dan tujuan pasien. Isi berisi perilaku verbal (mantra) dan nonverbal (gerakan dan ramuam). Penutup berisi harapan, ucapan terimakasih, dan salam.

Pada mantra pengobatan dan pencegahan sakit-penyakit adanya nomina penunjuk penyebab sakit seperti, asisik, awulu, kremi,dan ganaspati. Selain itu, adanya verba imperatif yang menunjukkan power tutulung seperti kata balia, elapana, dan aturi.

2) Struktur Makro dalam Ranah Kesehatan

Struktur makro pada peristiwa tutur merupakan unsur wajib dalam pengobatan dan pencegahan sakit-penyakit. Peristiwa tutur pada analisis etnografi selain mengkaji bentuk dan makna, juga mengkaji peristiwa tutur seperti dalam kajian Sosiolinguistik. peristiwa tutur terdiri dari delapan komponen yaitu sebagai berikut.

a) Tempat dan Waktu. Praktik pengobatan dan pencegahan sakit penyakit dilaksanakan ditempat tetulung atau di rempat pasien dengan waktu yang disesuaikan dengan kondisi tetulung dan pasien.

b) Peserta Tutur. Pada praktik pengobatan dan pencegahan sakit-penyakit, pihak-pihak yang terlibatr dalam tuturan adalah tetulung sebagai sosok penuyembuh, pasien sebagai orang yang menerima pengobatan atau pencegahan dari tetulung, dan/atau wali pasien sebagai orang yang mewakili pasien. 
c) Maksud dan Tujuan Tuturan. Pada pengobatan dan pencegahan sakitpenyakit, seorang pasien yang datang bermaksud untuk memohon pengobatan dan pencegahan sakit penyakit. Tujuan pasien yaitu untuk memperoleh kesembuhan secara fisik dan kedamaian rohani. Pada pengobatan dan pencagahan sakit penyakit, tetulung bermaksud mengobati dan mencegah sakit penyakit pasien. Tujuan tetulung yaitu agar pasien mendapat kesembuhan, pasien terhindar dari gangguan, dan tetulung mendapatkan imbalan (bagi sebagian penyebuh seperti Mbah Seger).

d) Pokok Tuturan. Pokok tuturan dalam pengobatan dan pencegahan sakit penyakit adalah kesehatan dan keselamatan. Bentuk bahasa yag digunakan adalah ragam bahasa santai dengan tingkat tutur ngoko dan krama.

e) Nada Tuturan. Perilau verbal dan nonverbal dalam pengobatan dan pencegahan sakit penyakit disampaikan dengan nada dan intonasi rendah. Hal ini semata-mata untuk menjaga kesakralan dan kekusyukan. Perilaku verbal dan nonverbal dalam praktik pengobatan dan pencegahan sakit penyakit antara tetulung dukun dan pasien menggunakan nada standar atau nada dalam percakapan pada umumnya. Sedangkan pada saat me-matek mantra, seorang dukun akan menggunakan nada dan intonasi yang rendah dan bahkan hampir tak terdengar oleh pasien atau mitra tutur.

f) Instrumen. Instrumen dalam praktik pengobatan dan pencegahan sakit penyakit adalah bahasa lisan. Bahasa lisan yang digunakan merupakan bahasa Jawa dialek Yogyakarta dengan tingkat tutur ngoko, krama madya, dan krama inggil. 
g) Norma. Norma atau aturan dalam berinteraksi yaitu tata krama bersikap dan berbicara. Seorang pasien ketika berbicara kepada tetulung akan bersikap dan berbicara dengan sopan dan santun.

h) Genre. Genre dalam pengobatan dan pencegahan sakit penyakit yaitu peristiwa tutur (percakapan) dan doa.

b. Ko-Teks Perilaku Nonverbal dalam Praktik Penyembuhan

Ko-teks perikaku verbal dapam praktik penyembuhan, yaitu (1) kinetik atau gerak dalam praktik penyembuhan sakit, terdapat perilaku nonverbal berupa kinetik atau gerak. Gerakan yang dilakukan terulung misalnya gerakan titik sakit, gerakan awal, gerakan inti, dan gerakan akhir. 2) Unsur material dalam prakti penyembuhan yaitu jamu atau ramuan untuk menyembuhkan sakit dan penyakit, saranan dan sesajii.

c. Konteks Perilaku Verbal dan Nonverbal dalam Praktik Penyembuhan

Sebuah tradisi lisan dalam praktik penyembuhan tidak dapat dipisahkan pada sebuah konteks. Makna, maksud, peran dan fungsi sebuah tradisi lisan dapat ditemukan dalam konteks budaya, situasi, sosial-ekonomi, dan spriritual.

3. Mengapa perilaku verbal dan nonverbal sangat penting dalam praktik penyembuhan penyakit pada masyarakat Dusun Tambran Kidul. Dalam praktek penyembuhan sakit-penyakit secara tradisional, perilaku verbal dan nonberbal merupakan satu kesatuan yang tidak dapat dipisahkan. Hal ini disebabkan oleh beberapa hal diantaranya, (a) perilaku verbal merupakan perwujudan iman dan harapan kepada Tuhan; (b) perilaku nonverbal merupakan perwujudan tindakan nyata; (c) Adanya inerenergi yang dimiliki para tetulung. 
4. Pola pikir, pandangan hidup, dan pandangan dunia dalam ranah kesehatan di Dusun Tambran Kidul, yaitu (a) pola pikir yang mencerminkan nilai-nilai tradisi masyarakat, seperti menjaga keharmonisan dengan alam dan sesama, kerukunan dan perdamaian, selalu eling lan waspodho 'ingat dan berjaga-jaga, menghormati leluhup, hidup sederhana, kehati-hatian atau teliti, dan suka monolong; (b) pandangan hidup yang mencerminkan nilai-nilai trasidi masyarakat, seperti tepa slira 'saling menghargai'; ayom 'kesejukan/kedamaian, ayem 'suasana hati yang tenteram', suka 'kehidupan yang menyenangkan'; asih samaning titah 'cinta kasih terhadap sesama'; dan ngluruk tanpo bolo, sugih tanpo bondo, dikdoyo tanpo aji; (c) pandangan dunia yang mencerminkan nilai-nilai trasidi masyarakat, seperti adanya kekuatan tertinggi (holly spririt), yaitu Tuhan; dan leluhur yang senantiasa melindungi, seperti Dhanyang dan Dewi Sri.

\section{SIMPULAN DAN SARAN}

Pada penelitian ini dapat disimpulkan sebagai berikut. 1) adanya pandangan sehat dan sakit; 2) perilaku verbal dan nonverbal dalam pengobatan dan pencegahan sakit-penyakit adanya teks, ko-teks, dna konteks. Teks meliputi struktur makro dna struktur mikro. Ko-teks meliputi gerak dan unsur material. Konteks meliputi konteks budaya, sosial, ekonomi, dan spriritual. 3) mengapa perilaku verbal dan nonverbal sangat penting dalam praktik penyembuhan penyakit karena, (a) perilaku verbal merupakan perwujudan iman dan harapan kepada Tuhan; (b) perilaku nonverbal merupakan perwujudan tindakan nyata; (c) adanya inerenergi yang dimiliki para tetulung. 4) Pola pikir, pandangan hidup, dan pandangan dunia dalam ranah kesehatan di Dusun Tambran Kidul, yaitu (a) pola pikir yang mencerminkan nilai-nilai tradisi 
masyarakat, seperti menjaga keharmonisan dengan alam dan sesama, kerukunan dan perdamaian, selalu eling lan waspodho 'ingat dan berjaga-jaga, menghormati leluhup, hidup sederhana, kehati-hatian atau teliti, dan suka monolong; (b) pandangan hidup yang mencerminkan nilai-nilai trasidi masyarakat, seperti tepa slira 'saling menghargai'; ayom 'kesejukan/kedamaian, ayem 'suasana hati yang tenteram', suka 'kehidupan yang menyenangkan'; asih samaning titah 'cinta kasih terhadap sesama'; dan ngluruk tanpo bolo, sugih tanpo bondo, dikdoyo tanpo aji; (c) pandangan dunia yang mencerminkan nilai-nilai trasidi masyarakat, seperti adanya kekuatan tertinggi (holly spririt), yaitu Tuhan; dan leluhur yang senantiasa melindungi, seperti Dhanyang dan Dewi Sri.

\section{DAFTAR PUSTAKA}

Abdullah, Wakit. 2013. Kearifan Lokal dalam Bahasa dan Budaya Jawa Masyarakat Nelayan di Pesisir Selatan Kebumen (Sebuah Kajian Etnolinguistik). Disertasi. Surakarta: Universitas Sebelas Maret.

Duranti, Alessandro.1997. Linguistic Anthropology. New York: Cambridge University Press.

Fernandez, Inyo Yos. 2015. Materi Mata Kuliah Etnolinguistik: Kajian Ilmu Disiplin Linguistik dan Antropologi. Surakarta: Universitas Sebelas Maret.

Foley, W. A. 1997. Anthropological Linguistics An Introduction. University of Sydney: Blackwell Publishers.

http://harmokosaja.blogspot.com/2013/06/persepsi-masyarakat-tentang-sehat-sakit.html.

Katubi. 2011. Bahasa, Kebudayaan Material, dan Tradisi Lisan: Studi Etnolinguistik Orang Kui di Alor, Nusa Tenggara Timur. Penelitian Program Nasional Bidang Bahasa, Pusat Kemasyarakatan dan Kebudayaan-LIPI.

Koentjoroningrat. 2000. Pengantar Ilmu Antropologi. Jakarta: Rineka Cipta.

Mahsun. 2011. Metode Penelitian Bahasa: Tahapan Strategi, Metode, dan Tekniknya. Jakarta: PT Rajagrafindo Persada. 
Mudjisunu, dr. Hartono. 1984. Kesehatan Menurut Orang Jawa. Yogyakarta: Yayasan Ilmu Pengetahuan dan Kebudayaan Panunggal Lembaga Javanologi.

Robson, Stuart \& Yacinta Kurniasih. 2000. Bijdragen: Describing Character in Javanese Three Grammatical Categories. Jakarta: KITLY Press Agency in Indonesia.

Sibarani, Robet. 2004. Antropologi Linguistik (Antropologi Linguistik-Linguistik Atropologi). Medan; penerbit Poda.

Spradley, James P. 2007. Metode Etnografi (penerjemah misbah Zulfa Elizaberh). Yogyakarta: Tiara Wacaba Yogya.

Subroto, Edi. 2011. Pengantar Studi Semantik dan Pragmatik (Buku 1. Pengantar Studi Semantik). Surakarta: Cakrawala Media.

Sugianto, Alip.2014. Gaya Bahasa dan Budaya Mantra Warok Rerog Ponorogo ( Kajian Etnolinguistik). Tesis. Surakarta: Universitas Sebelas Maret.

Sukarno. 2005. Bahasa Ritual Pertanian Sawah Petani Jawa Tradisional (Studi Kasus di Desa Plosorejo Kecamatan Matesih Kabupaten Karanganyar). Tesis. Surakarta: Universitas Sebelas Maret.

Taum, Yoseph Yapi. 2011. Studi Sastra Lisan Sejarah, Teori, Metode dan Pendekatan Disertai Contoh Penerapannya. Yogyakarta: Lamalera.

Tim KKN. 2013. Laporan Kuliah Kerja Nyata (KKN). Yogyakarta: Universitas Sarjanawiyata. Tamansiswa.

Wahyono. 2013. "Ethnicity as Identity in Packaging Design og Traditional Medicine (Jamu) for Women." International Conference on Indonesian Studies. Fakultas Ilmu Pengetahuan Budaya Universitas Indonesia di Yogyakarta: 1314 Juli.

Wakit Abdullah.2013. Kearifan Lokal dalam Bahasan dan Budaya Jawa Mayarakat Nelayan di Pesisir Selatan Kebumen (Sebuah Kajian Etnolinguistik). Disertasi. Surakarta: Universitas Sebelas Maret.

Walangarei, Sjane F. 2013. "Sikap dan Perilaku Mayarakat Terhadapap Simbol-simbol Budaya: Suatu Kajian Etnolinguistik.” International Conference on Indonesian Studies. Fakultas Ilmu Pengetahuan Budaya Universitas Indonesia di Yogyakarta: 13-14 Juli.

Widodo, Wahyu. 2012. Mantra Kidung Jawa (Kajian Repetisi dan Fungsi). Tesis. Surakarta: Universitas Sebelas Maret. 